\title{
Head Soft Tissue Necrosis, CTCAE
}

National Cancer Institute

\section{Source}

National Cancer Institute. Head Soft Tissue Necrosis, CT CAE. NCI Thesaurus. Code C58383.

A disorder characterized by a necrotic process occurring in the soft tissues of the head. 